\title{
MAY 81962
}

$$
\begin{aligned}
& \text { IDO-19030 } \\
& \text { CEND-135 } \\
& \text { Supplement to } \\
& \text { Vol. I } \\
& \hline
\end{aligned}
$$

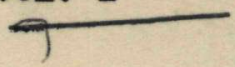

PL FINAL DESIGN REPORT

SUPPLEMENT

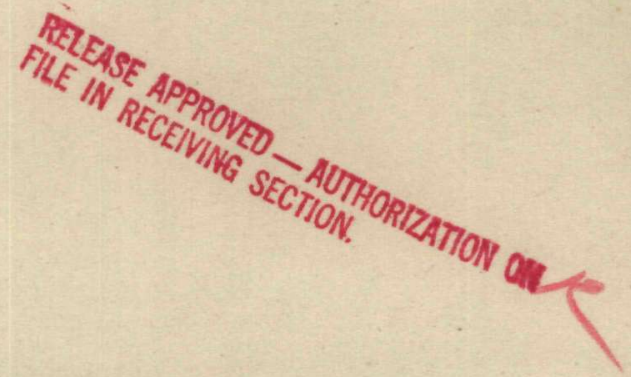

Contract AT-(10-1)-967

and

Contract AT-(11-1)-1062

U. S. Atomic Energy Commission

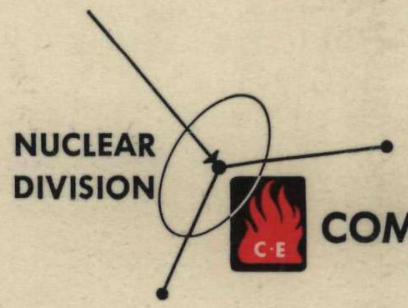


IDO-19030

CEND-135

Supplenent to

volume it

PL FINAL DESIGN REPORT

SUPPLEMENT

Contract AT- $(10-1)-967$
and
Contract AT- $(11-1)-1062$

U. S. Atomic Energy Commission

Classification:

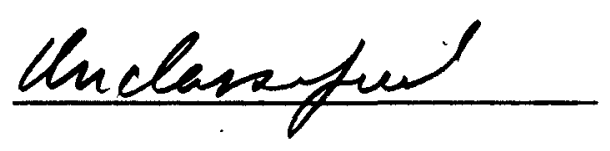

B. Swlw $3 / \mathrm{s} / 6 / \mathrm{C}$
Approved:
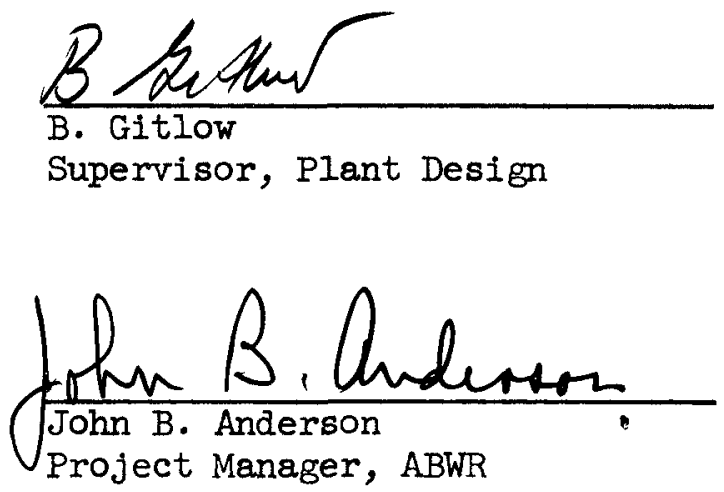

COMBUSTION ENGINEERING, INC.

NUCLEAR DIVISION

Windsor

Connecticut 


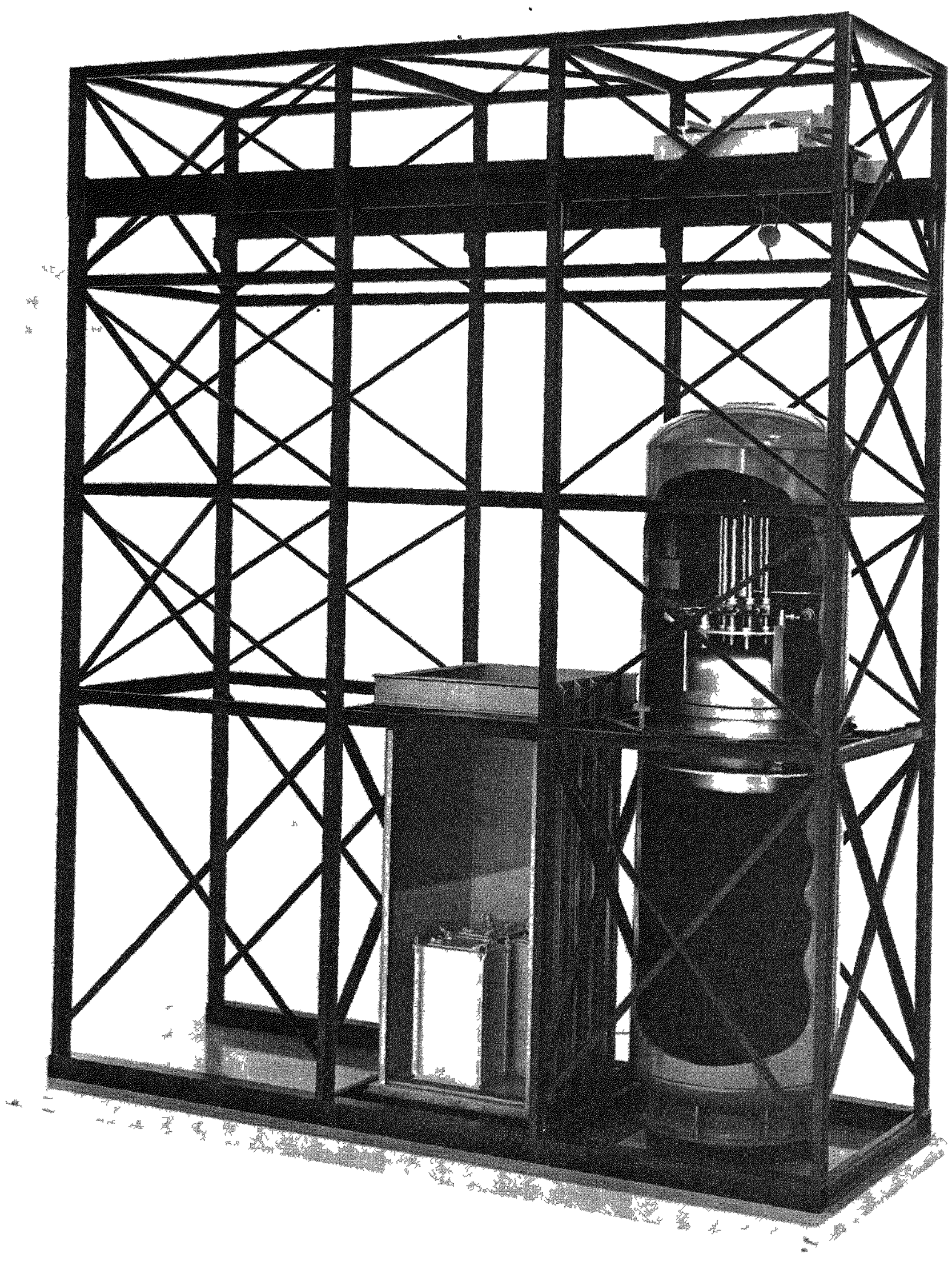

- 


\section{DISCLAIMER}

This report was prepared as an account of work sponsored by an agency of the United States Government. Neither the United States Government nor any agency Thereof, nor any of their employees, makes any warranty, express or implied, or assumes any legal liability or responsibility for the accuracy, completeness, or usefulness of any information, apparatus, product, or process disclosed, or represents that its use would not infringe privately owned rights. Reference herein to any specific commercial product, process, or service by trade name, trademark, manufacturer, or otherwise does not necessarily constitute or imply its endorsement, recommendation, or favoring by the United States Government or any agency thereof. The views and opinions of authors expressed herein do not necessarily state or reflect those of the United States Government or any agency thereof. 


\section{DISCLAIMER}

Portions of this document may be illegible in electronic image products. Images are produced from the best available original document. 
In June, 1961 Combustion Engineering, Inc. under Contract AT-(10-1)-967 with the Atomic Energy Commission published the PL Final Design Report which is a detail description of the PL-2 Reactor Plant. At that time certain supplemental work was considered advisable. This report contains two parts. Part I describes the PL refueling equipment and refueling procedures in more detail than was presented in IDO-I9030 and also presents the results of some recent design changes. Part II presents a definitive hardware design for the radioactive gas handling equipment which is described in IDO-19030.

This supplemental work was carried out under Contract AT-(11-1)-1062 with the Chicago Operations Office of the Atomic Energy Commission. 


\section{DISTRIBUTION}

U. S. Atomic Energy Commission (5)

Washington 25, D. C.

ATTN: Chief, Water Systems Projects Branch

Army Reactors, DRD

Mail Station F-31l

U. S. Atomic Energy Commission

Washington 25, D.C.

ATTN: Chief, Technical Evaluation Branch

Army Reactors, DRD

Mail Station F-31I

U. S. Atomic Energy Commission

Washington 25, D.C 。

ATTN: Chief, Water Reactors Branch

Civilian Reactors, DRD

Mail Station F-311

U. S. Atomic Energy Commission (2)

Chicago Operations Office

9800 South Cass Avenue

Argonne, Illinois

ATTN: Mr. F. Mattmueller

Director, Contracts Division

U. S. Atomic Energy Commission

Chicago Operations Office

9800 South Cass Avenue

Argonne, Illinois

ATTW: Director, Reactor Engineering Division

U. S. Atomic Energy Commission

New York Operations Office

376 Hudson Street

New York 14, New York

ATTN: Army Reactors Project Officer

Nuclear Power Field Office (2)

Engineer Research and Development Laboratories

Fort Belvoir, Virginia

ATIN: Chief, Operation Support Branch 
Nuclear Power Field Office

Engineer Research and Development Laboratories Fort Belvoir, Virginia

ATTN: Chief, Operations Branch

Nuclear Power Field office (2)

Engineer Research and Development Laboratories Fort Belvoir, Virginia

ATIN: Chief, Training Branch

Office, Chief of Engineers

Nuclear Power Division

Building $\mathrm{T}=7$

Washington 25, D. C.

ATTN: Chief, Projects Branch

Office, Chief of Engineers (2)

Nuclear Power Division

Building T-7

Washington 25, D。C.

ATTN: Health Physics and Safety Officer

U. S. Atomic Energy Commission

Washington 25, D. C.

ATTN: Chief, Evaluation and Planning Branch

Civilian Reactors, DRD

Mail Station $\mathrm{F}-311$

Nuclear Power Field Office (2)

Engineer Research and Development Laboratories

Fort Belvoir, Virginia

ATTN: Training Branch

(Navy Personnel)

U. S. Atomic Energy Commission

Washington 25, D. C.

ATTN: Air Force

Army Reactors, DRD

Mail Station F-3ll 
U. S. Atomic Energy Commission (3) + one reproducible Reference Branch

Technical Information Service Extension

P. 0. Box 62

Oak Ridge, Tennessee

U. S. Atomic Energy Commission (3)

Idaho Operations Office

P. O. Box 2108

Idaho Falls, Idaho

ATTIN: E. W. Bosse, Director

Reactor Division

U. S. Atomic Energy Commission (2)

Idaho Operations Office

P. O. Box 2108

Idaho Falls, Idaho

ATTN: Director, Division of Health and Safety

U. S. Atomic Energy Commission (1)

Idaho Operations Office

P. O. Box 2108

Idaho Falls, Idaho

ATIN: W. A. Erickson, Director

Contract Administration Division

Idaho Nuclear Power Field Office (3)

P. O. Box 2558

Idaho Falls, Idaho

ATTN: Captain R. L. Morgan, Chief, INPFO

U. S. Army CRREL

Hanover, New Hampshire

ATIN: Frederjck J. Sanger

Argonne National Laboratory (2)

9800 South Cass Avenue

Argonne, Illinois

ATTN: Director, Technical Information Division 
NRTS Technical Library (20)

Phillips Petroleum Company

P. O. Box 2067

Idaho Falls, Idaho

ATTN: Report Section

The Martin Company

Nuclear Division

Baltimore 3, Maryland

ATTN: Resident Engineer, PM-I

Alco Products, Inc.

One Nott

Schenectady 5, New York

ATTN: Manager, Engineering Atomic Energy Department

Union Carbide Nuclear Corporation

Oak Ridge National Laboratories

P. O. BOX Y

Oak Ridge, Tennessee

ATTN: Associate Director

Reactor Projects Division 


\section{DISTRIBUTION}

Combustion Engineering, Inc., Windsor

L. E. Anderson

H. Cahn

W. S. Flinn

R. H. Gale

B. Gitlow

R. L. Hoover

R. W. Lauffer

D. J. McLaughlin

J. J. Satchwell

S. Visner

E. W. Woollacott

W. H. Zinn

Document Control (2)

Project File 


\section{TABLE OF CONTENTS}

Page

Part I Refueling

1

A. Refueling Equipment 1

B. Refueling Procedure 3

Part II Gas Handling 5 


\section{ILLUSTRATIONS}

Figure No.

Page

1

Spent Fuel Shipping Cask

6

2

Transfer Cask

7

3

Refueling Plate Assembly

8

4

Refueling Plate Positions

9

5

Adapter

10

6

Refueling Shroud

11

7

Three Principle Steps in Removal of a Fuel Element

12

8

Machinery Arrangement, Gas Handling Skid, Package \#1

13

9

Gas Handling Skid, Package \#2

14 
REFUELING

A description of the refueling procedure was given in Volume I of the PL Final Design Report. At that time the design of the refueling equipment and the refueling procedure had not been finalized. In the ensuing period improvements were made in the procedure and the design of the refueling equipment was completed. This supplement furnishes the additional design information and changes necessary to complete the refueling description. It contains the following:

(1) A description of the refueling equipment.

(2) Illustrations of the refueling equipment and refueling procedure.

(3) An outline of the refueling procedure.

The basic steps in the refueling operation are the same as those outlined in Volume I of the Final Design Report except for (1) the addition of the adapter piece for removal of fuel elements and (2) the addition of the shroud for the transfer of fuel elements and control rods into the shipping casks.

\section{Refueling Equipment}

The fuel elements and control rods are transported in shipping casks as shown in Figure 1. These casks are fabricated from stainless steel and are designed to permit the stacking of one cask on another in the spent fuel tank. They are provided with sufficient lead shielding to reduce the radiation level on the outside of the casks to the permissible shipping requirements (gamma radiation of $200 \mathrm{mr} / \mathrm{hr}$ at surface and $10 \mathrm{mr} / \mathrm{hr}$ at one meter) when spent fuel elements are being handled, Each cask is designed to hold eight fuel elements and three control rods. The fuel elements are separated and enclosed by boral plates in order to eliminate the possibility of accidental criticality. The casks are so designed that the fuel elements and control rods are held in position by Bellevilile-type springs at top and bottom. The head is attached by recessed socket head cap screws to provide a flat top surface for stacking. When lowered into place on top of the loaded cask, the weight of the head compresses the springs, thus applying the required vertical loading to hold the contents in place during shipment. Tre fixtures in the head which house the springs are provided with lead-in to cns sre centering of the elements and control rods.

The transfer cask, Figure 2, is used to transfer fuel elements and control rods between the reactor and the shipping casks. The cask is cylindrical in shape and consists of concentric stainless steel shells enclosing lead shielding. The interior of the cask has been sized to accommodate either a fuel assembly or a control rod. The lifting mechanism is mounted in the top of 
the cask. A handwheel operating through a worm drive mechanism raises or lowers a cylindrical shaft by means of a rack and pinion arrangement. The shaft projects through the top of the cask and is attached to a gripper inside the cask. Additional sections are added to the shaft to enable the gripper to reach the top of the core. A cylinder valve at the base of the cask permits the entry and withdrawal of elements with no reduction in shielding during the operation. This valve is operated from the top of the cask.

The refueling plate assembly, Figure 3 , is placed on the reactor vessel flange after removal of the head. It is used as a shield and a support for refueling equipment during removal of fuel elements and control rods from the reactor vessel. The alignment ring is first placed in position on the reactor flange and aligned by means of the two guide pins in the reactor flange. The refueling plate is then placed on the alignment ring in the desired position. Figure 4 illustrates the four possible positions of the plate during refueling. The plate is located and aligned in each case by means of the indexing pin. The plate is provided with three openings each furnished with a removable plug. The two larger plugs have smaller plugged openings to permit removal of fuel elements. This arrangement provides access to all fuel assemblies and control rods for removal with the transfer cask. (Fig. 3 is identifical to Fig. 69 -Volume II.)

The adapter, Figure 5, is a stainless steel transition piece which is placed in the small openings of the indexing plate during removal of a fuel element from the reactor into the transfer cask in order to prevent radiation streaming through the annular opening.

The refueling shroud, Figure 6 , is a rectangular structure constructed of steel plate sandwiching four inches of lead on the four sides. The top is open and the base consists of a steel supporting structure with an opening fitted with hinged gratings for passage of the fuel elements and control rods. The shroud is used as an intermediate component between the transfer cask and the shipping casks in the spent fuel tank. The shroud is mounted on the shipping cask; the element or rod is transferred from the transfer cask into the shroud and rested on the grating; the transfer cask is removed and the final transfer from shroud to shipping cask is performed with hand tools.

The principal steps in the refueling operation are illustrated in Figure 7. Step 1 shows the removal of a fuel element from the reactor. The refueling plate is positioned on the reactor so that one of the two large openings in the plate is over the element to be removed. Figure 4 illustrates the four positions of the refueling plate necessary for the renoval of a complete core. Orientation of the plate is controlled by the indexing pin. The adapter is put in place on the refueling plate opening over the element to be removed. The transfer cask is then positioned on the adapter plate; the cylinder valve is opened and the fuel element is picked up by means of the gripper and retracted into the cask and secured. The cylinder valve is then closed. The smaller openings in the refueling plate are used as access ports for lights, hand tools, and viewing. 
Step 2 shows the fuel element in position in the refueling shroud as it is being unloaded from the transfer cask and placed on the floor grating of the shroud. The transfer cask is then removed.

Step 3 illustrates the transfer of an element from the shroud to the shipping cask by means of a hand tool. The element is lifted clear of the floor grating. The grating is then swung open using another hand tool. The element is then lowered through the grating and into its final position in the shipping cask.

All the fuel elements and control rods can be removed in a similar manner by indexing the refueling plate in the proper position as shown in Figure 4. The center control rod must be moved laterally to center it under one of the openings in the refueling plate before removal.

\section{Outline of Refueling Procedure}

(1) The covers are removed from the three shipping casks in the spent fuel tank.

(2) The shroud is placed on one of the shipping casks.

(3) The spent fuel tank is filled.

(4) The manhole on the containment vessel is opened.

(5) The motor drives and all piping and wiring are disconnected as necessary for removal of the containment vessel upper portion.

(6) The control rod actuator assemblies are removed.

(7) The containment vessel flange is unbolted.

(8) The upper portion of the containment vessel is moved to the open bay, placed on a skid in the vertical position and skidded through the large access door into the tunnel.

(9) The water level instruments are removed.

(10) The reactor head is unbolted, moved to the open bay and placed on a skid.

(11) The alignment ring and the refueling plate, Figure 3 , are installed on the reactor flange.

(12) The refueling plate is indexed over the first fuel element to be removed.

(13) The adapter piece is put in position on the index plate.

(14) The transfer cask, Figure 2, is removed into the open bay and unbolted from the skid. 
(15) The transfer cask is lifted into position on the adapter and the cylinder valve is opened.

(16) The gripper j.s lowered and connected to the fuel element. The viewing access holes in the plate are used during this operation.

(17) The element is retracted into the cask.

(18) The cylinder valve is closed.

(19) The transfer cask is lifted, using the overhead crane, to a position above the spent fuel tank and lowered on to the refueling shroud.

(20) The cylinder valve is opened; the fuel element is lowered from the transfer cask into the shroud and disengaged.

(21) The gripper is retracted, the cylinder valve closed and the cask is removed from the spent fuel tank.

(22) Transfer of the removed element from the shroud into the shipping cask is performed using manual tools.

(23) Steps 11 through 22 are then repeated for each spent fuel element.

(24) The procedure for control rod blade removal is similar to that for fuel element removal except that the adapter piece is not required.

(25) The refueling plate is indexed for direct removal of all control rod blades except the center one. To accomplish this, the center blade must be lifted first from the access holes and then swung into position over the location of a previously removed blade. From this position it is lifted vertically.

(26) Refueling of the reactor is performed following the same procedure as for initial fueling except that refueling will be done through the refueling plate due to residual activity of core structurals and the pressure vessel.

(27) The reactor head is replaced and bolted using a new gasket and filler.

(28) The reactor complex is then re-assembled following steps 15 through 23 of the erection procedure. 


\section{PART IS}

\section{RADIOACTIVE GAS HANDLING}

The gas handling equipment for the system described in Volume I of the PL Final Design Report has been arranged on two skids. One skid contains the heat exchanger and refrigeration equipment and the other the charcoal adsorption beds.

The machinery arrangement of the heat exchanger and refrigeration equipment is shown in Figure 8. There are two refrigeration units. Each unit includes a compressor, a compressor motor, air cooled condenser, expansion tank, receiver tank, demister, and refrigeration heat exchanger. In addition to the refrigeration equipment, the skid contains the cooler, moisture separator, moisture trap, main system fan, cooler fan, condensate trap and cooler motor. The total weight of machinery on the skid is 7,187 pounds. The supporting structural steel weighs 3,800 pounds for a combined total of 10,987 pounds. The outline dimensions of the package are $8^{\prime}-6^{\prime \prime}$ height $\times 6^{\prime}-0^{\prime \prime}$ width $\times 17^{\prime}-7^{\prime \prime}$ length.

The charcoal adsorption beds are supported for shipment and final installation as shown on Figure 9. The outline dimensions of the package are $6^{\prime}-11^{\prime \prime}$ height x 8'-6" width $x$ 15'-2" length, and the total weight is 8,540 pounds. 

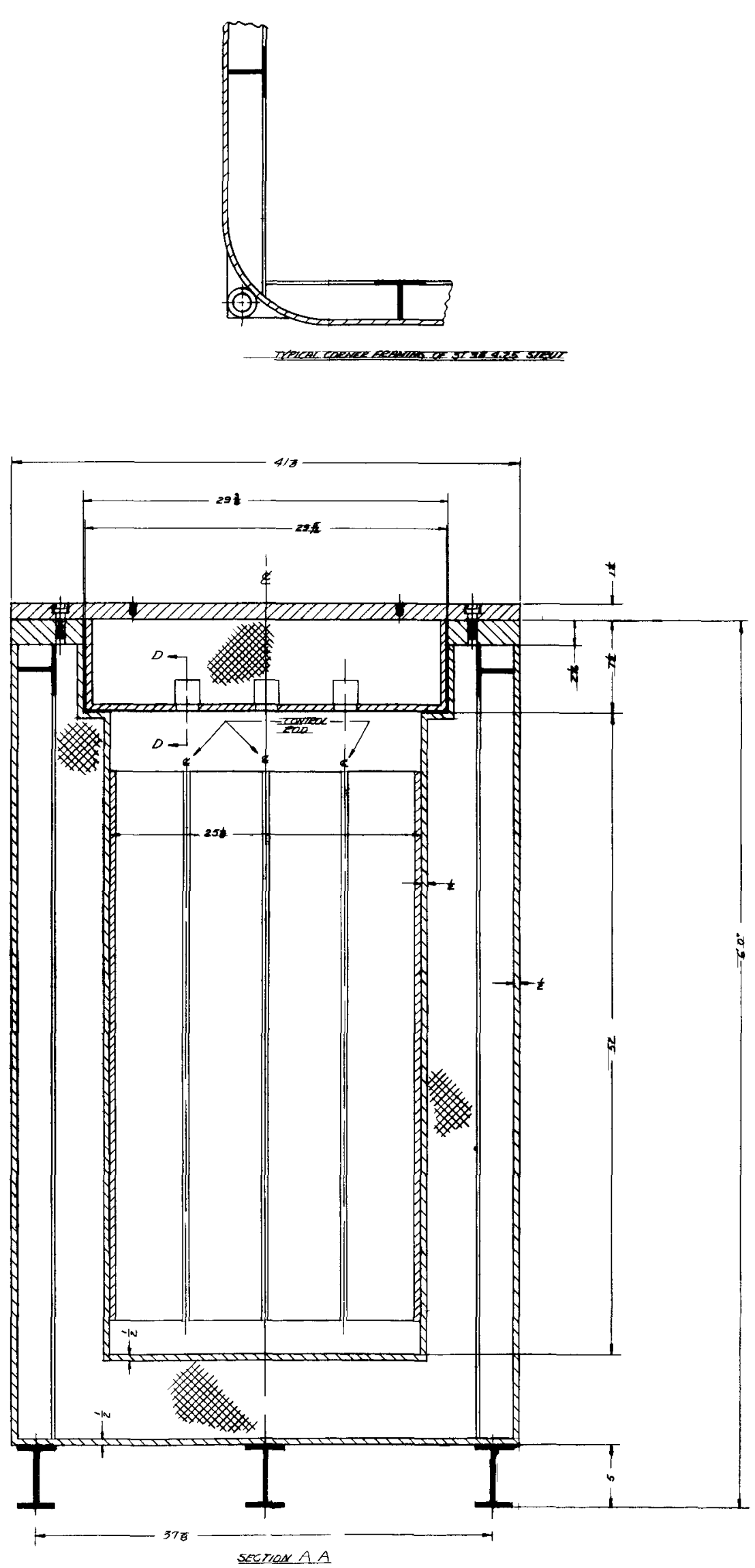
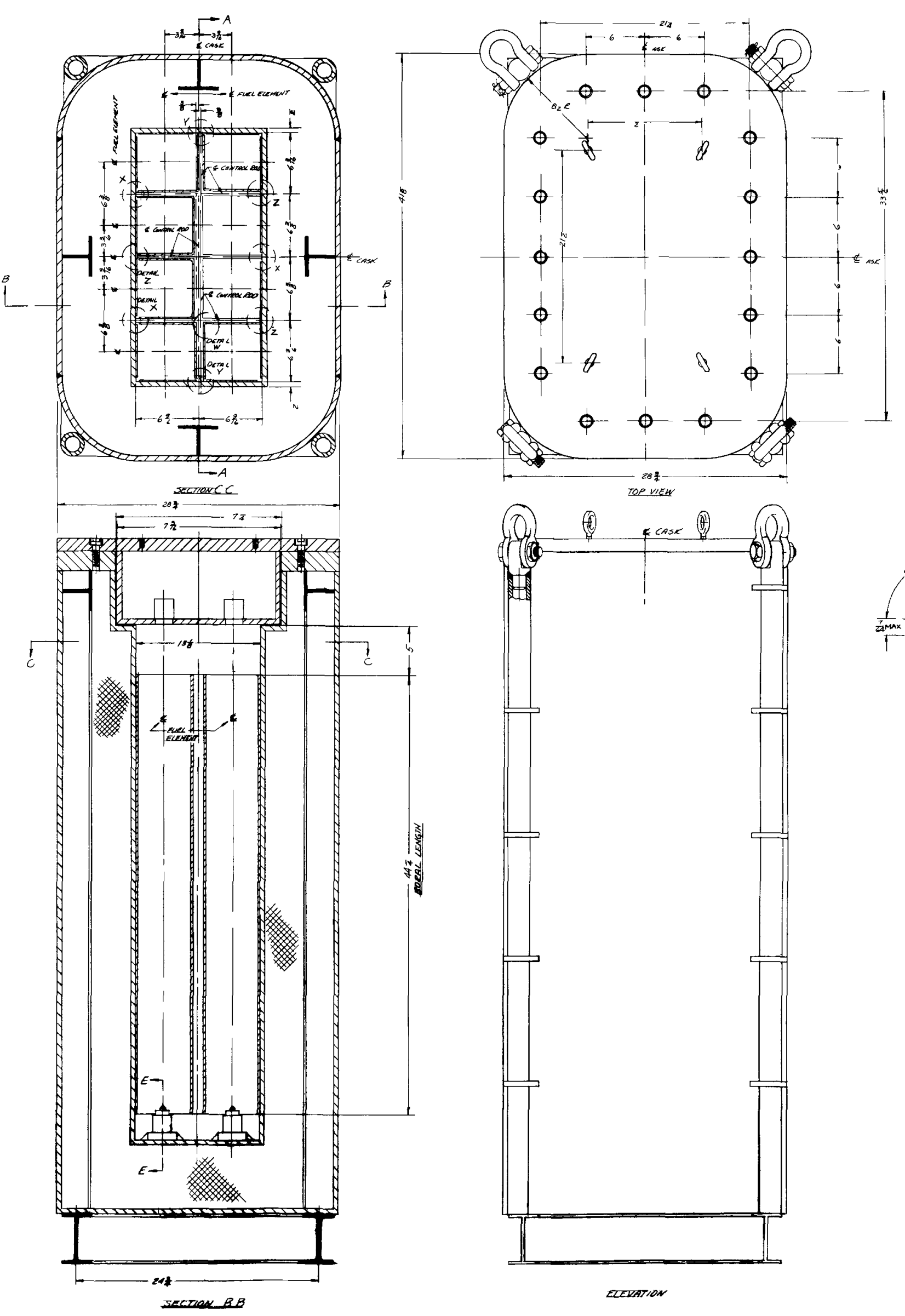
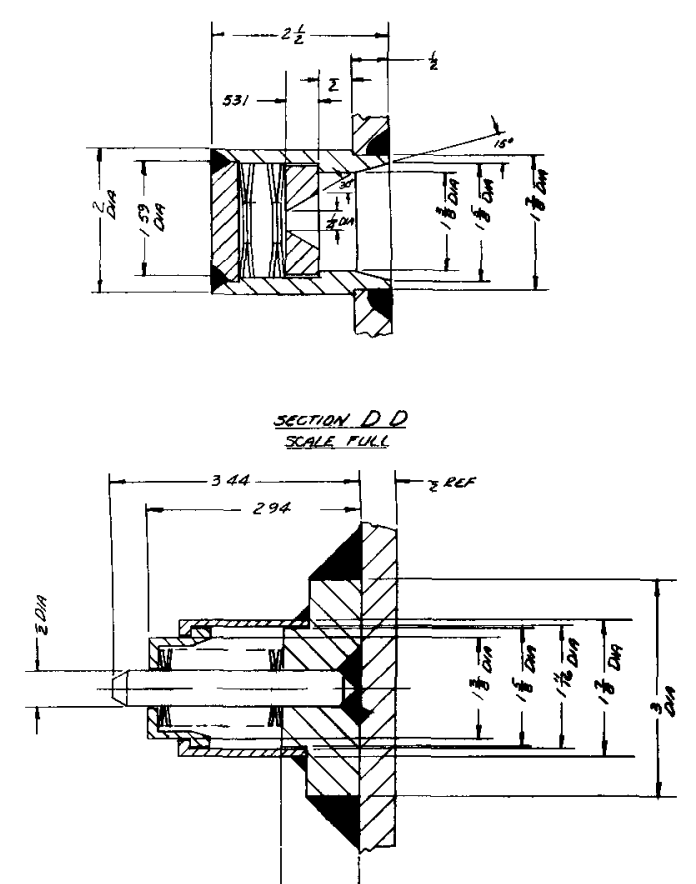

$C_{4 R}^{\infty}$

secones EE

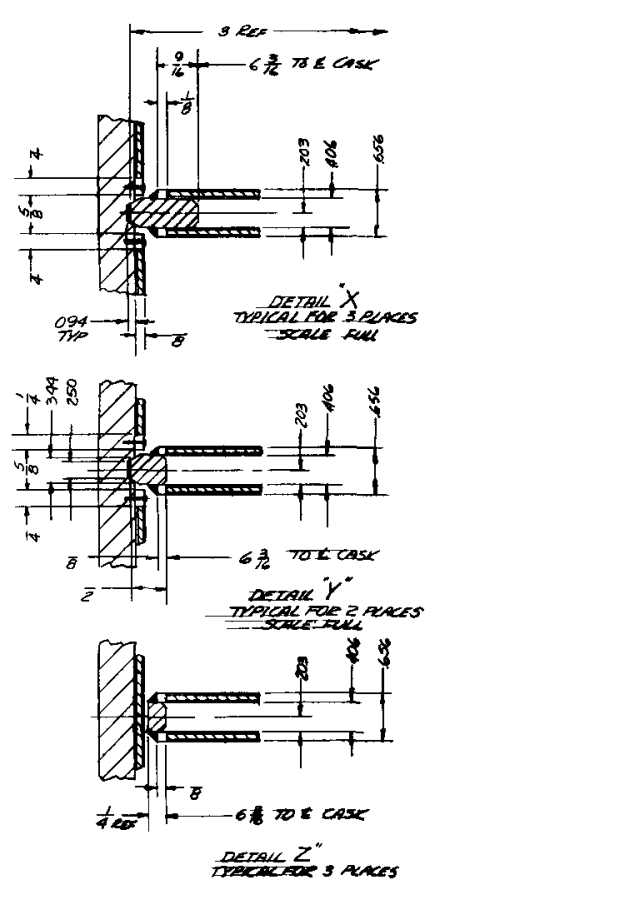

SPENT FUEL SHIPPING CASK 

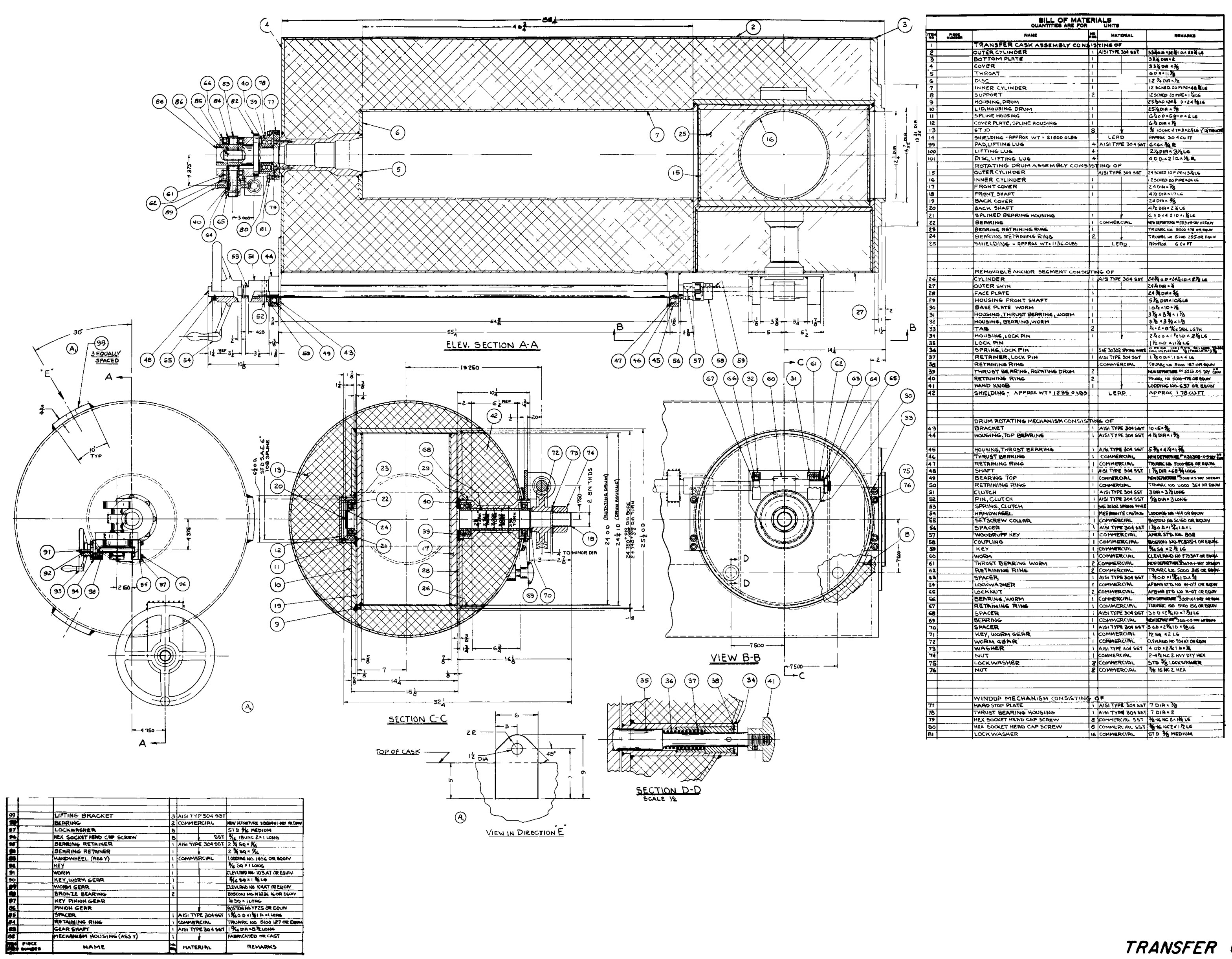

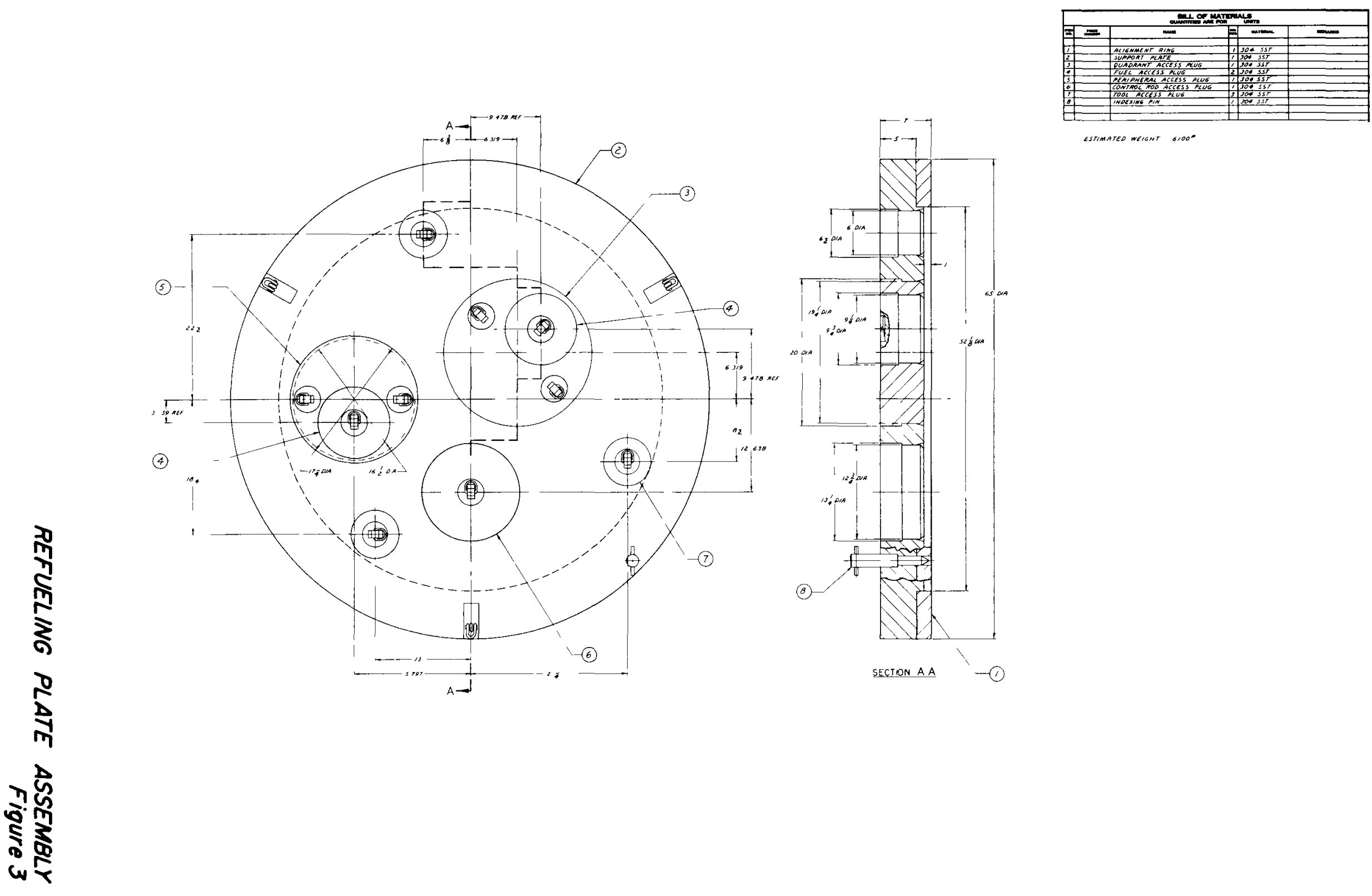

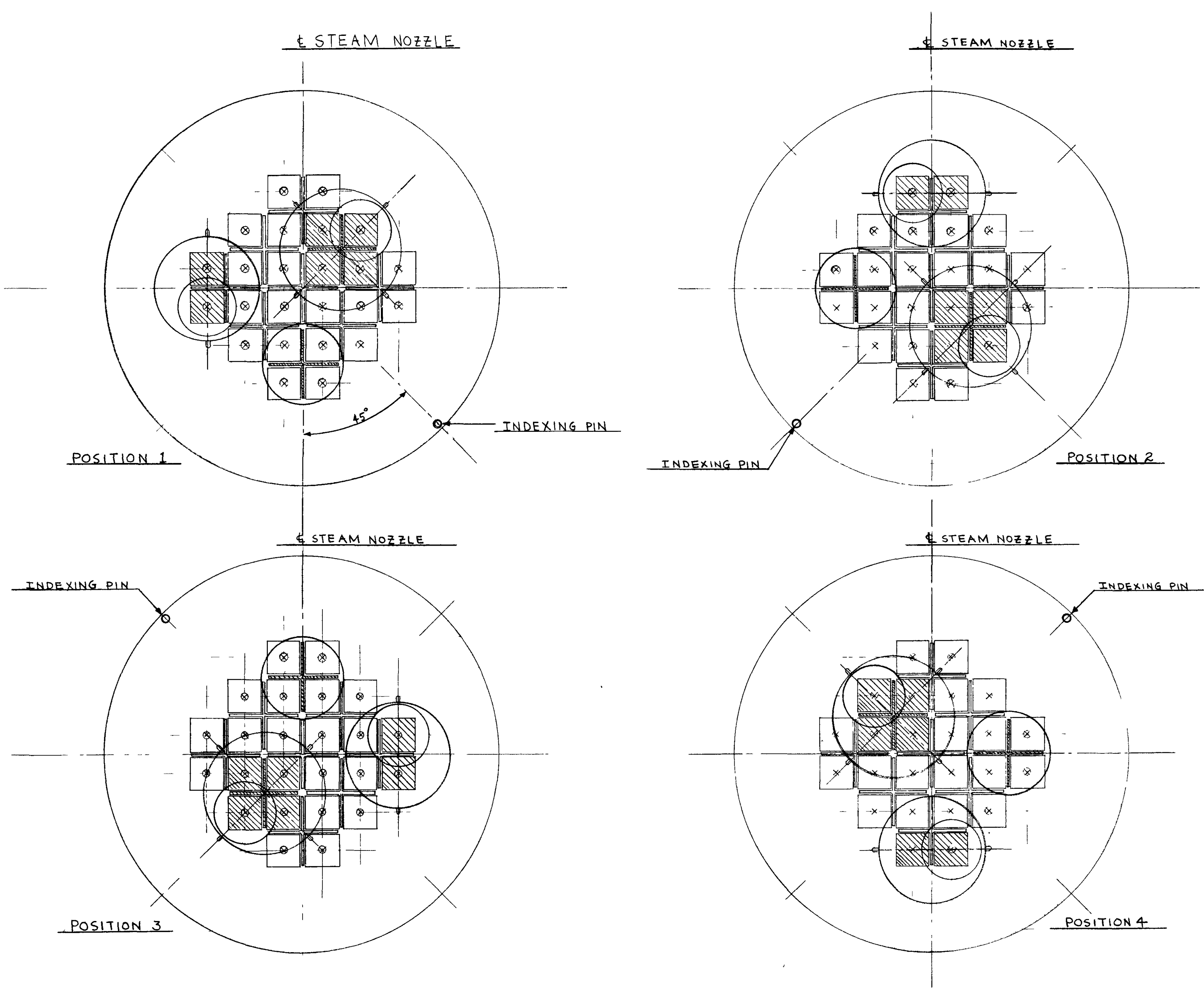


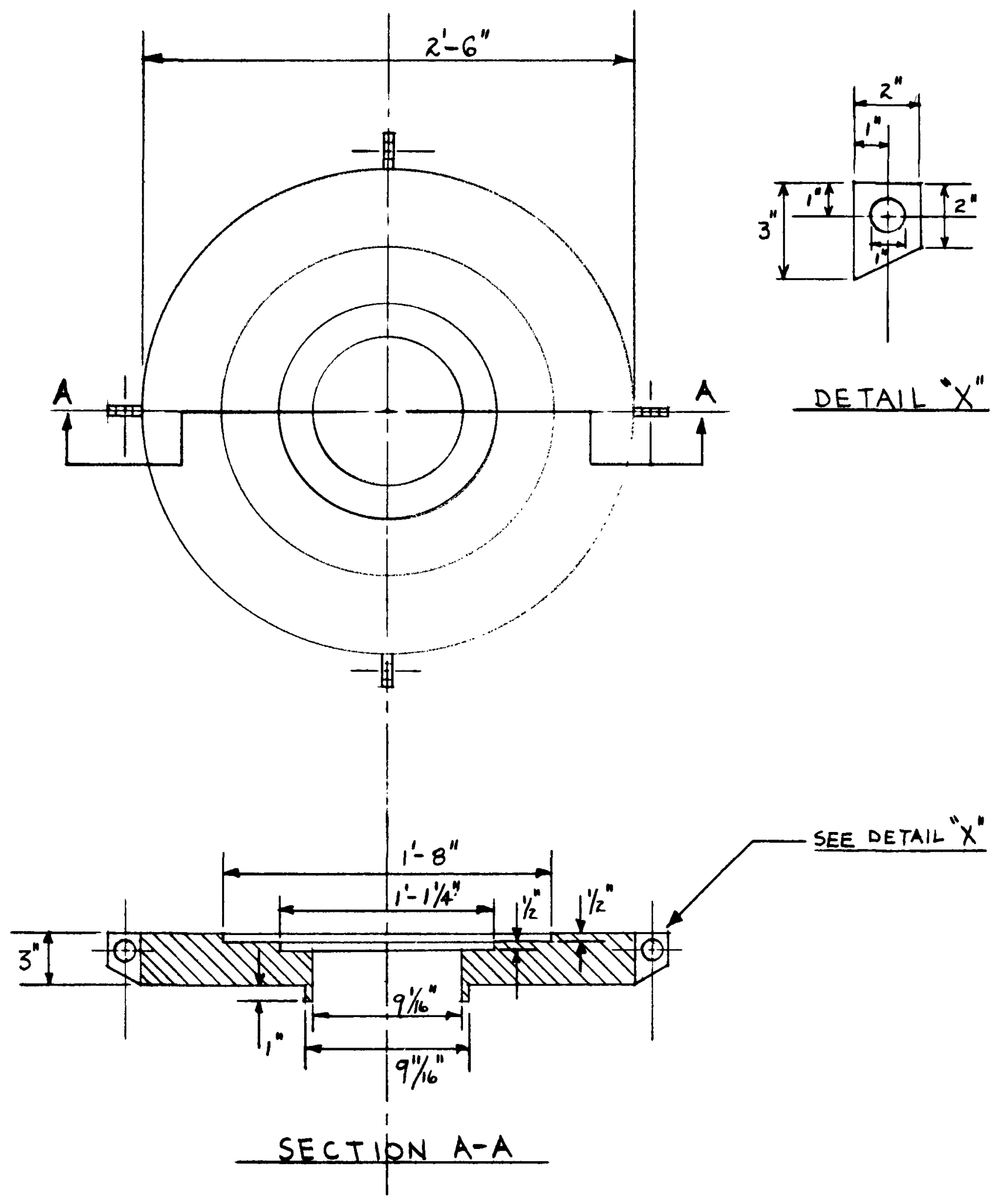

ADAPTER, FUEL ELEMENT REMOVAL 

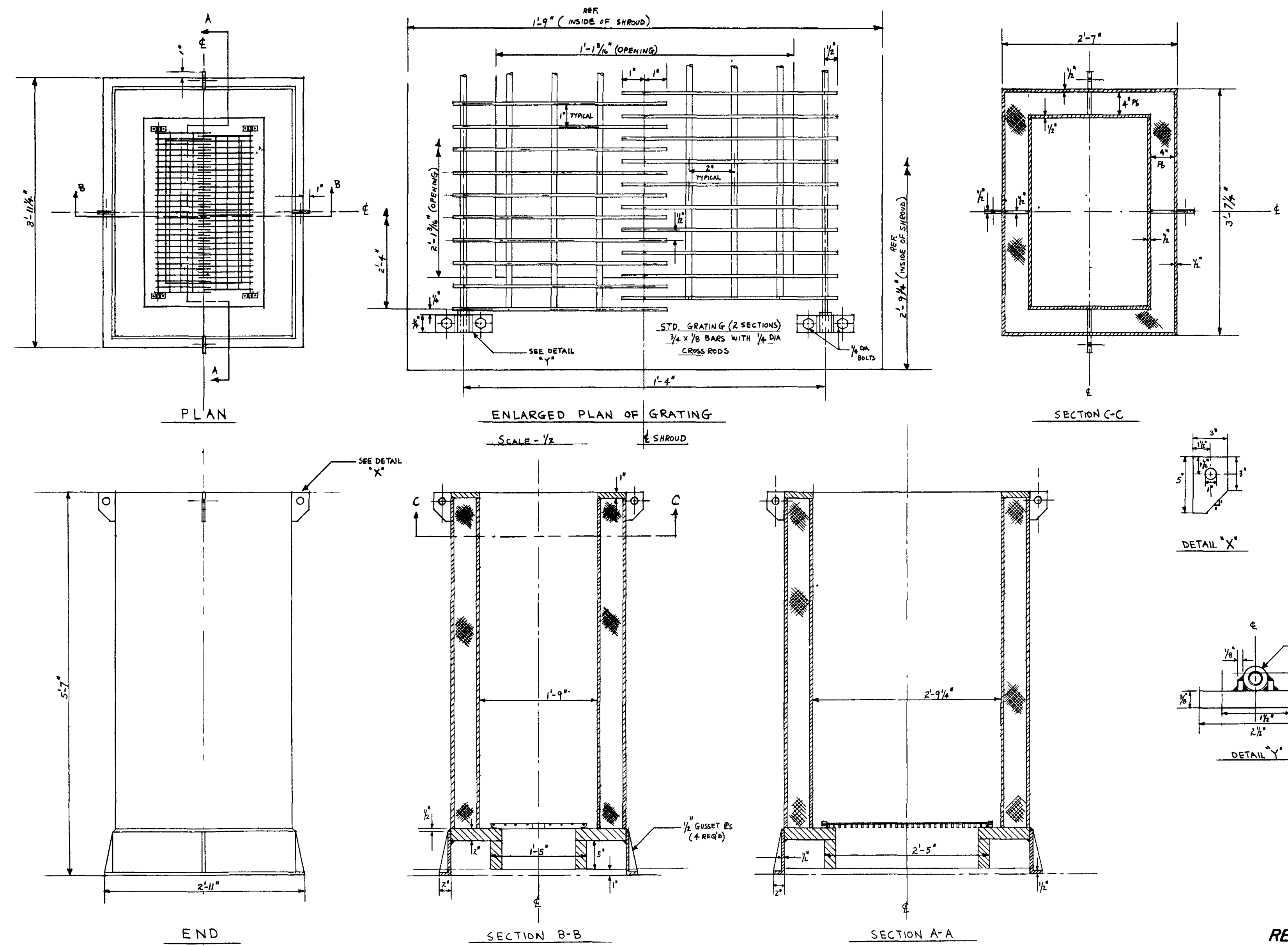

DETAIL $X$ "

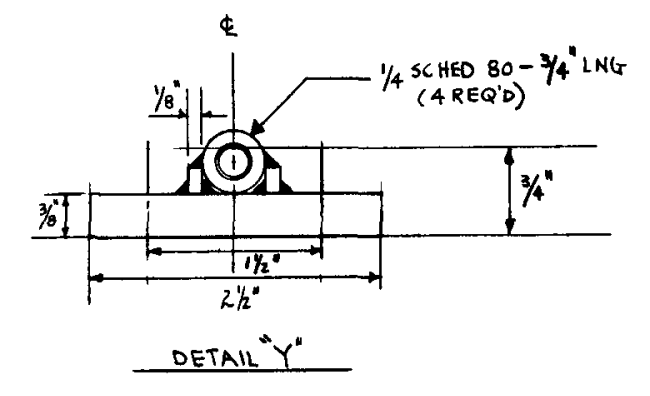



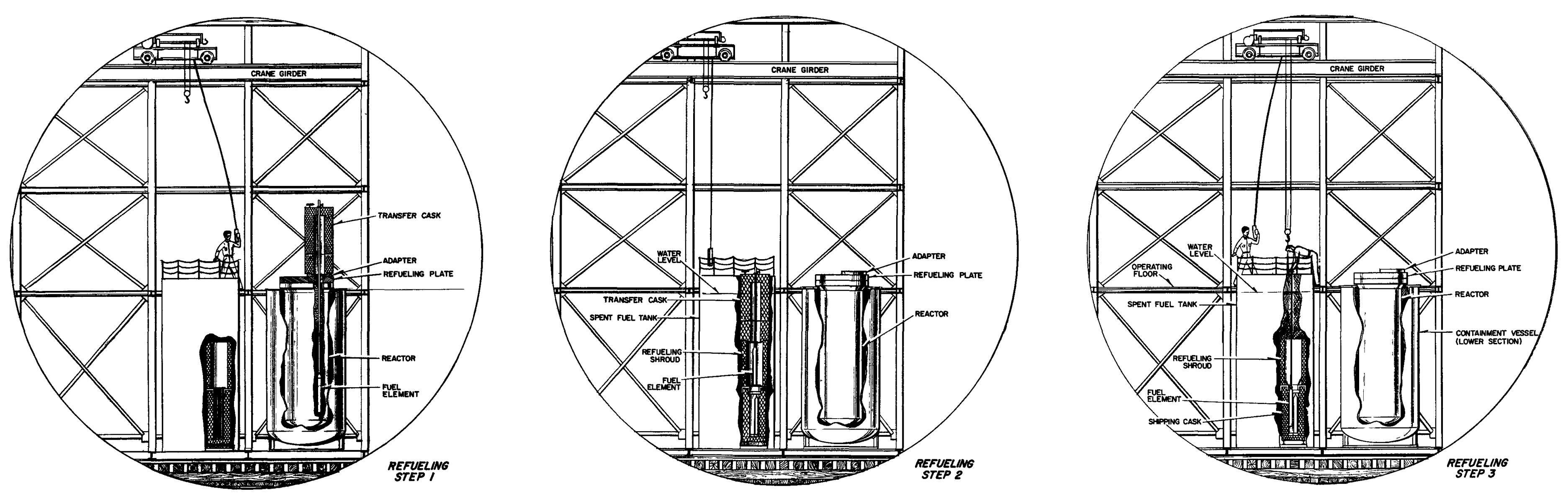


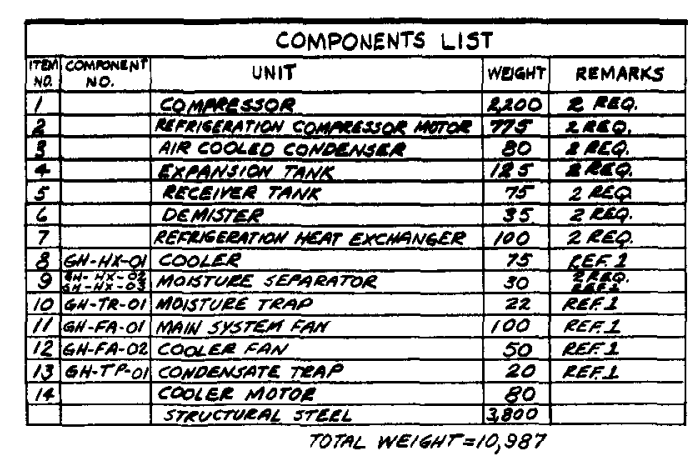

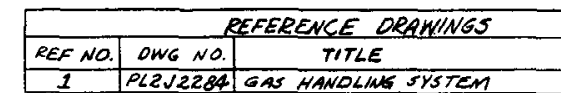
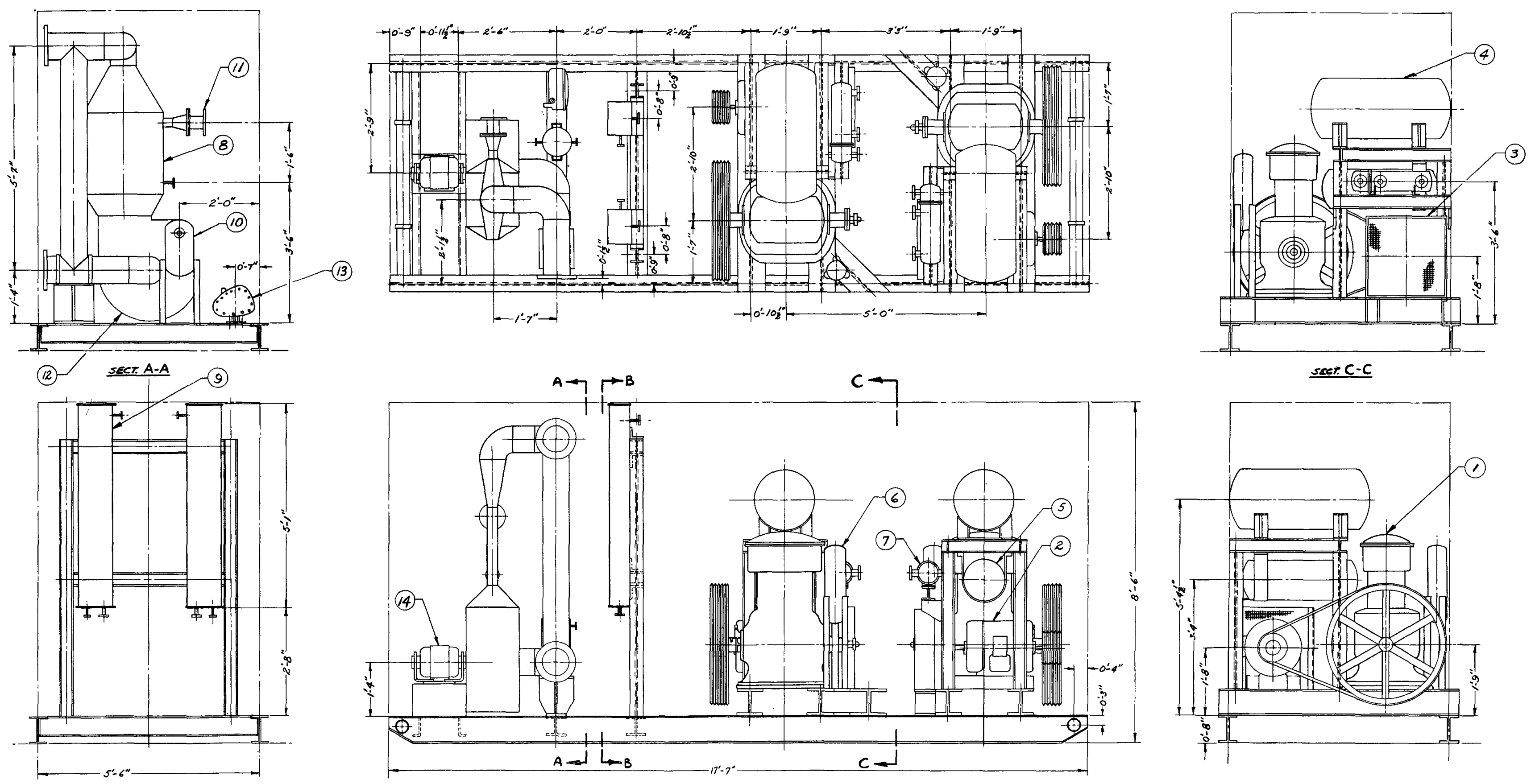


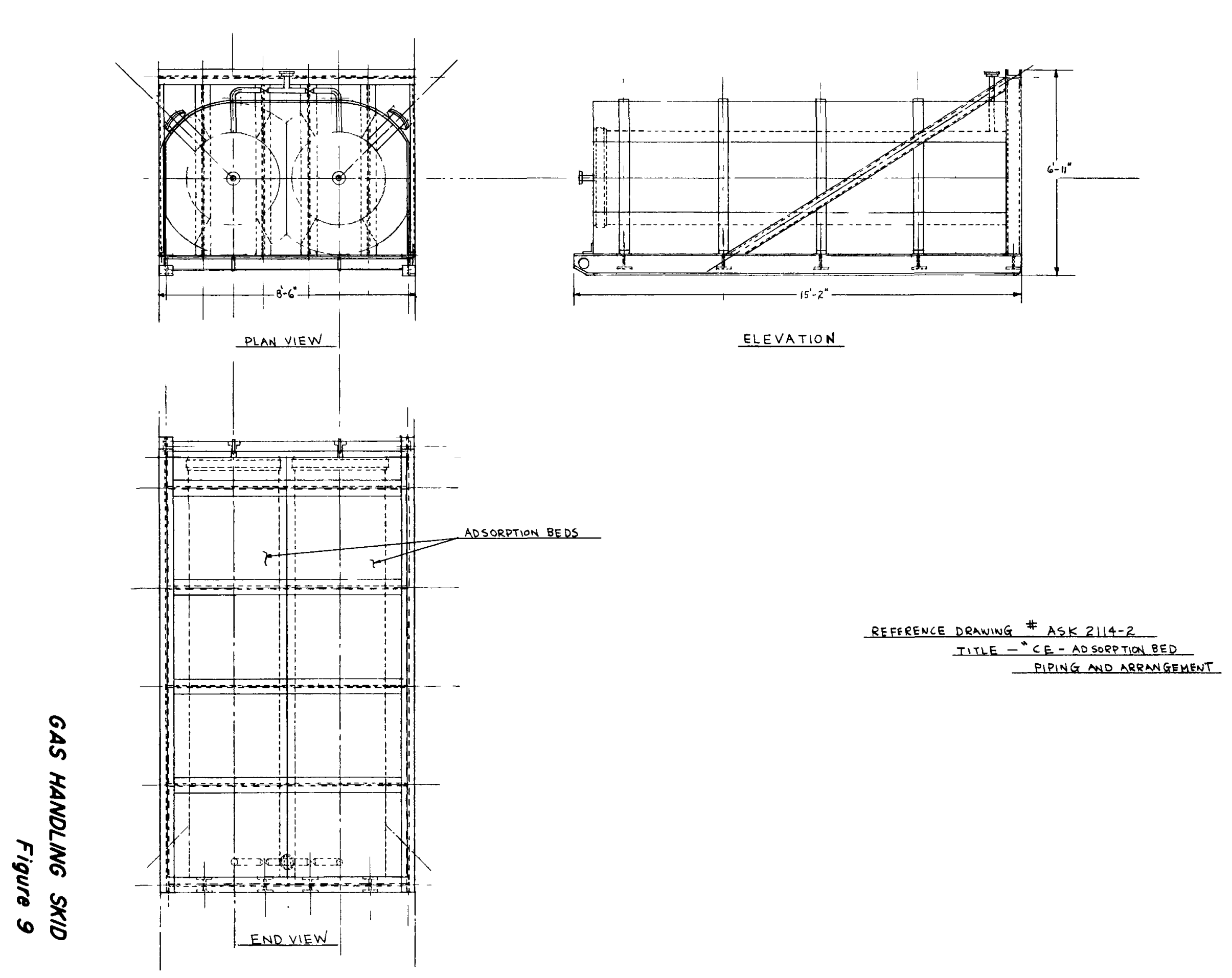

